PERM JOURNAL OF PETROLEUM AND MINING ENGINEERING

ВЕСТНИК ПНИІУ. ГЕОЛОГИЯ. НЕФТЕГАЗОВОЕ И ГОРНОЕ ДЕЛО

ISSN 2224-9923

Volume / Том 20 №1 2020

http://vestnik.pstu.ru/ge

UDC 622.276(470.53)

Article / Статья

(C) PNRPU / ПНИПУ, 2020

\title{
ENHANCING THE EFFICIENCY OF GAS-OIL (OIL-GAS) DEPOSITS DEVELOPMENT BASED ON SELECTION OF OPTIMAL ENGINEERING SOLUTIONS FOR PERM REGION FIELDS
}

\section{Olga R. Goncharova, Sergey V. Kozlov}

PermNIPIneft branch of LUKOIL-Engineering LLC in Perm (3a Permskaya st., Perm, 614015, Russian Federation)

\section{ПОВЫШЕНИЕ ЭФФЕКТИВНОСТИ РАЗРАБОТКИ \\ ГАЗОНЕФТЯНЫХ (НЕФТЕГАЗОВЫХ) ЗАЛЕЖЕЙ НА ОСНОВЕ ПОДБОРА ОПТИМАЛЬНЫХ ПРОЕКТНЫХ РЕШЕНИЙ ДЛЯ МЕСТОРОЖДЕНИЙ ПЕРМСКОГО КРАЯ}

\section{О.Р. Гончарова, С.В. Козлов}

Филиал ООО «ЛУКОЙЛ-Инжиниринг» «ПермНИПИнефть» в г. Перми (614015, Россия, г. Пермь, ул. Пермская, 3а)

Received / Получена: 22.06.2019. Accepted / Принята: 10.01.2020. Published / Опубликована: 02.03.2020

Key words:

efficiency enhancement, integrated development, oil and gas deposit, gas cap, oil rim, water-alternatinggas injection, fine water-gas mixture.
Development of oil, gas and gas-condensate fields, with commingled fluid extraction at some of them, is the specifics of hydrocarbons production in Perm Region. Reserves of free gas and gas caps occur at every fifth field under development in Perm Region.

There are conditions for implementing combined multifunctional technologies at the interface of liquid and gaseous fluid development. At the same time, transformation of a pseudo-negative factor - gas presence - into a positive vector can significantly enhance the efficiency of hydrocarbon resources development.

An integrated approach to effective development of oil and gas deposits is considered in the article. Geological and technological features of oil and gas deposits, such as the type of oil and gas deposit, the ratio of gas and oil reserves, the type of reservoir, the mobility of oil reserves, the permeability anisotropy ratio and the water drive strength, were taken into account. Considerable attention was paid to working agents. The authors have analysed various technologies and technical solutions being implemented: formation pressure maintenance system (water, gas), water-alternating-gas injection (injection of water-gas mixture and fine watergas mixture), gas lift, and barrier water-flooding. In this case, the emphasis was made on active development system.

As a result, suggestions on the enhancement of the oil and gas deposits development efficiency have been offered, subject to geological and technological features. As an example of implementing an integrated approach using active gas energy technologies, an oil and gas facility at a Perm Region field was examined. The current state was analysed and the main development issues were identified. Recommendations on the commingled development of the gas cap and oil rim subject to the gas-oil contact immobility and the application of fine water-gas mixture injection technology are provided.

Особенностью добычи углеводородов на территории Пермского края является разработка как нефтяных, так газовых и газоконденсатных месторождений, на части из них реализована совместная добыча флюидов. Запасы свободного газа, а также газовых шапок имеются на каждом пятом разрабатываемом месторождении Пермского края.

На стыке разработки жидких и газообразных флюидов возникают предпосылки для реализации комбинированных, многофункциональных технологий. При этом трансформация псевдонегативного фактора - наличия газа в положительный вектор может значительно повысить эффективность освоения ресурсов углеводородов.

В статье рассмотрен комплексный подход к вопросу эффективной разработки нефтегазовых залежей. При нем учитывались геологические и технологические особенности нефтегазовых залежей, такие как тип нефтегазовой залежи, соотношение запасов газа и нефти, тип коллектора, подвижность запасов нефти, коэффициент анизотропии проницаемости, активность водонапорного режима. Значительное внимание уделялось агентам воздействия. Авторами выполнен анализ различных реализуемых технологий и технических решений: система поддержания пластового давления (вода, газ), водогазовое воздействие (закачка водогазовой смеси и мелкодисперсной водогазовой смеси), газлифт, барьерное заводнение. Акцент в данном случае сделан на активную систему разработки.

В результате даны предложения по повышению эффективности разработки нефтегазовых залежей с учетом геологических и технологических особенностей. В качестве примера реализации комплексного подхода с применением активных технологий использования энергии газа рассмотрен нефтегазовый объект одного из месторождений Пермского края. Выполнен анализ текущего состояния, определены основные проблемы разработки. Даны рекомендации по совместной разработке газовой шапки и нефтяной оторочки с условием неподвижности газонефтяного контакта и применению технологии закачивания мелкодисперсной водогазовой смеси.

\footnotetext{
Гончарова Ольга Разимовна - инженер 1-й категории отдела проектирования и мониторинга разработки Северной группы месторождений (тел.: +007 34223534 36, e-mail: Olga.R.Goncharova@pnn.lukoil.com). Контактное лицо для переписки.

Козлов Сергей Васильевич - ведущий инженер отдела проектирования и мониторинга разработки Осинской и Кунгурской групп месторождений (тел.: +007342 23534 36, e-mail: Sergej.Kozlov@pnn.lukoil.com).

Olga R. Goncharova - Engineer of the $1^{\text {st }}$ category of the Design and Monitoring Department of the North Group of Fileds (tel.: +007342 235 3436 , e-mail: Olga.R.Goncharova@pnn.lukoil.com). The contact person for correspondance.

Sergey V. Kozlov - Lead Engineer of the Design and Monitoring Department of the Osa and Kungur Group of Fields (tel.: +007 342 235 34 36, e-mail: Sergej.Kozlov@pnn.lukoil.com).
} 


\section{Introduction}

Development of oil, gas and gas-condensate fields, with commingled fluid extraction at some of them, is the specifics of hydrocarbons production in Perm Region. Reserves of free gas and gas caps are present at every fifth field under development in Perm Region. As of today, according to the resource base analysis, $7 \%$ of the remaining recoverable oil reserves are complicated by the presence of a gas cap. The largest gas cap reserves are those of the Kokuyskoye, Magovskoye, Pavlovskoye and Batyrbayskoye fields [1]. Currently, twelve deposits with annual natural gas production exceeding 500 million $\mathrm{m}^{3}$ are being developed.

Oil and gas technologies of the 21 st century feature a whole range of specific aspects. Today, the idea of creating intelligent wells is being increasingly developed. These are multilateral, multifunctional and comprehensively monitored and controlled wells. The multifunctionality implies a combination of gas and water injection processes, and commingled withdrawal of gas, oil, condensate and water. These engineering solutions include numerous technical and process techniques to utilise the energy of free or dissolved gas in the processes of liquid formation fluid production. In addition, there is a significant degree of freedom when due consideration is given to the presence of gaseous hydrocarbons. Combined multifunctional technologies emerge at the interface of liquid and gaseous fluids development. The transformation of a pseudo-negative factor - the presence of gas into a positive vector can significantly enhance the efficiency of hydrocarbon resources development.

During the development and operation of oil and gas deposits, a significant amount of actual, experimental and empirical data has been accumulated in addressing the issue of oil and gas deposits development $[2,3]$. At the same time, we do not yet have a clear understanding that specially designed studies of wells and reservoirs can provide us with forward-looking information on future processes to be encountered during the life cycle of a field. As an example, there are deposits with extensive porous fractured reservoir rock development. Insufficient account of natural and induced reservoir fractures in geological and hydrodynamic models has a negative impact on the development performance. First of all, there is a growing probability of failure to take into account the premature water breakthrough, as well as blocking of oil reserves in the primary matrix. Clearly, conducting experiments on core samples is not enough here, as they cannot provide answers to the principal question what the anisotropy parameter is and do not allow obtaining phase permeability for the system of fractures and pores. Hydrodynamic simulation is also subjective in this aspect. Therefore, the authors believe that the most effective way to obtain the necessary information is an integrated approach covering laboratory experiments and simulation, as well as field tests of water (gas) portions injection into the oilsaturated zone and/or premature gas and water breakthrough at 1 or 2 wells, with subsequent interpretation of the data obtained. That means that the currently practiced pilot operation of wells and separate areas is replaced by a new trend in the geophysical well-logging methods -addressing the needs of development engineering, which is an active method of the well and reservoir study.

Such technologies are equally important in terms of reducing the total investment costs required. The facilities for gas transportation are expensive and take considerable time for construction, which entails conservation of oil (gas) reserves and is often the reason of unprofitability of the field development project [4-6].

\section{Integrated Approach to Effective Development of Oil and Gas Deposits}

The following development systems have been implemented in the Perm Region over the thirtyeight-year history of oil and gas deposits development:

- oil rim only;

- gas cap only; and

- integrated development of gas cap and oil rim.

Depending on the existing and anticipated reservoir-drive mechanisms, a certain development system can be the most effective one. For example, 
for gas-cap drive, when only oil rim is developed, gas is injected only to drive oil, and the gas-oil contact (GOC) moves in the direction of the oil zone of the deposit, resulting in gas breakthroughs. If, however, only the gas cap is developed in the gas-cap drive, there is an inevitable significant pressure drop in the gas zone as part of the process, and then, as the reservoir pressure $P_{\text {res }}$ falls below the saturation pressure $P_{\text {sat }}$, the oil deposit enters the dissolved gas drive.

In case of water drive, when either oil rim or gas cap only is developed, the fluid withdrawal is not fully replaced, and thus, pressure in the oil and gas zones of the deposit drops. The pressure drop rate is determined by the strength of the aquifer and its connectivity with the deposit (Table 1).

The work [7] studies the selection matrix for a development method of an oil-rim deposit. A number of factors were taken into account, including the mobility of oil reserves, the gas and oil reserves ratio, the strength of water drive, etc. This matrix is supplemented with several parameters, including a deposit type indicator. The deposit type is a morphometric measure of reserves (thickness of the oil rim and gas cap, and contact area), which determines the decisions related to the selection of an effective development system (Fig. 1).

Since oil and gas are marketable products, the authors believe that the integrated development of the gas cap and oil rim is preferable, with certain accommodations [8].

At the same time, for effective management of an oil and gas deposit development, it is necessary to withdraw oil and gas in such proportions that the gas cap and the oil rim are in equilibrium

Table 1

\section{Oil and Gas Deposits Drives}

\begin{tabular}{|c|c|c|c|}
\hline \multirow{2}{*}{ Drive } & \multicolumn{3}{|c|}{ Fluids Withdrawal } \\
\hline & Oil & Gas & Oil + Gas \\
\hline Gas Cap (GC) & $\begin{array}{l}\text { - The gas is injected only to drive } \\
\text { oil. } \\
\text { - GOC moves } \\
\text { towards the deposit oil zone }\end{array}$ & $\begin{array}{l}\text { - Significant pressure drop in the } \\
\text { deposit gas zone. } \\
\text { - GOC moves towards gas cap. } \\
\text { - At } P_{\text {res }}<P_{\text {sat }} \text {, oil deposit enters } \\
\text { dissolved gas drive }\end{array}$ & $\begin{array}{l}\text { Energy potential reduction during } \\
\text { deposit development }\end{array}$ \\
\hline Water-Drive & $\begin{array}{l}\text { - Oil and water withdrawal is not } \\
\text { fully replaced. } \\
\text { - GOC moves } \\
\text { towards the deposit oil zone }\end{array}$ & $\begin{array}{l}\text { - Pressure drop in oil and gas } \\
\text { zones of the deposit. } \\
\text { - The pressure drop rate is } \\
\text { determined by the strength of the } \\
\text { aquifer and its connectivity with } \\
\text { the deposit }\end{array}$ & $\begin{array}{l}\text { - Pressure drop and gas withdrawal } \\
\text { in the gas zone is partially replaced } \\
\text { by injection and migration of oil } \\
\text { into the gas deposit. } \\
\text { - GOC and OWC lift rate control } \\
\text { mechanism }\end{array}$ \\
\hline Elastic-Water-Drive & $\begin{array}{l}\text { - Oil withdrawal is fully replaced. } \\
\text { - GOC is in relative equilibrium }\end{array}$ & $\begin{array}{l}\text { - Gas withdrawal is fully replaced. } \\
\text { - OWC is in relative equilibrium }\end{array}$ & $\begin{array}{l}\text { Gas, oil and water withdrawal is } \\
\text { fully replaced by injection and } \\
\text { strength of edge and bottom water }\end{array}$ \\
\hline
\end{tabular}

$\mathrm{N}$ o t e : OWC is oil-water contact.

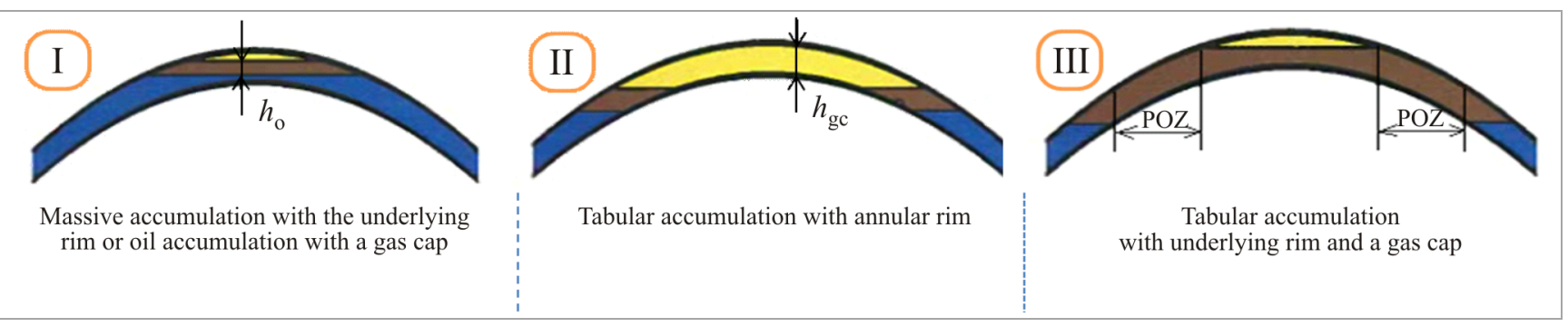

Fig. 1. Main types of two-phase accumulations: $h_{\mathrm{o}}$ is the oil zone thickness; $h_{\mathrm{gc}}$ is the gas cap thickness; POZ is a pure oil zone 
(i.e., the minimal draw-down on the GOC eliminates the breakthrough of fluids), since any significant movement of the gas-oil contact causes irrecoverable oil losses and reduction of the ultimate recovery factor.

From the equation of oil and gas reserves in place using the method of material balance for different drives and conditions of deposit development [9]:

$$
Q_{\mathrm{o}}+Q_{\mathrm{w}}+Q_{\mathrm{g}}+Q_{\mathrm{dg}}=\varepsilon_{\mathrm{o}}+\varepsilon_{\mathrm{r} . \mathrm{w}}+\varepsilon_{\mathrm{g}}+\varepsilon_{\mathrm{w}}+\varepsilon_{\mathrm{w} . \mathrm{fpm}}
$$

where $Q_{\mathrm{o}}, Q_{\mathrm{w}}, Q_{\mathrm{g}}, Q_{\mathrm{dg}}$ is production of oil, water, natural and dissolved gas; $\varepsilon_{\mathrm{o}}$ is oil expansion; $\varepsilon_{\text {r.w. }}$ is expansion of the rock-bound water system; $\varepsilon_{\mathrm{g}}$ is expansion of free gas in the gas cap; $\varepsilon_{\mathrm{W}}$ is water breakthrough (edge water, underlying water); and $\varepsilon_{\mathrm{w} . \mathrm{fpm}}$ is water injection.

The left-hand member of the equation is the amount of fluids extracted from the reservoir: oil, water, natural and oil gas, while the right-hand member represents the drives to extract this liquid and gas. If the relative equilibrium of the deposit and the immobility of the GOC and OWC is taken as a foundation, we can see the mechanism of control over the development of the oil-gas (gasoil) deposit through the withdrawal of natural gas in those areas where it is necessary to adjust the current position of the GOC in terms of the integrated approach.

When choosing an effective development system, in addition to the morphometric parameters of the deposit, the reservoir permeability was taken into account.

According to empirical data on the ratio of pore channel sizes $(d, \mu \mathrm{m})$ and the permeability coefficient $\left(K_{\mathrm{p}}, \mathrm{mD}\right)$ for the oil fields in the Perm Region, as well as the criteria of different technologies applicability (including cost-efficiency), the authors have elaborated a quantitative matrix of recommended technologies subject to the working agent selection (Fig. 2) [10-15].

Besides, when selecting effective development technologies, it is important to take into account a number of qualitative and quantitative factors, such as the reservoir type, the permeability anisotropy coefficient, and the well location.

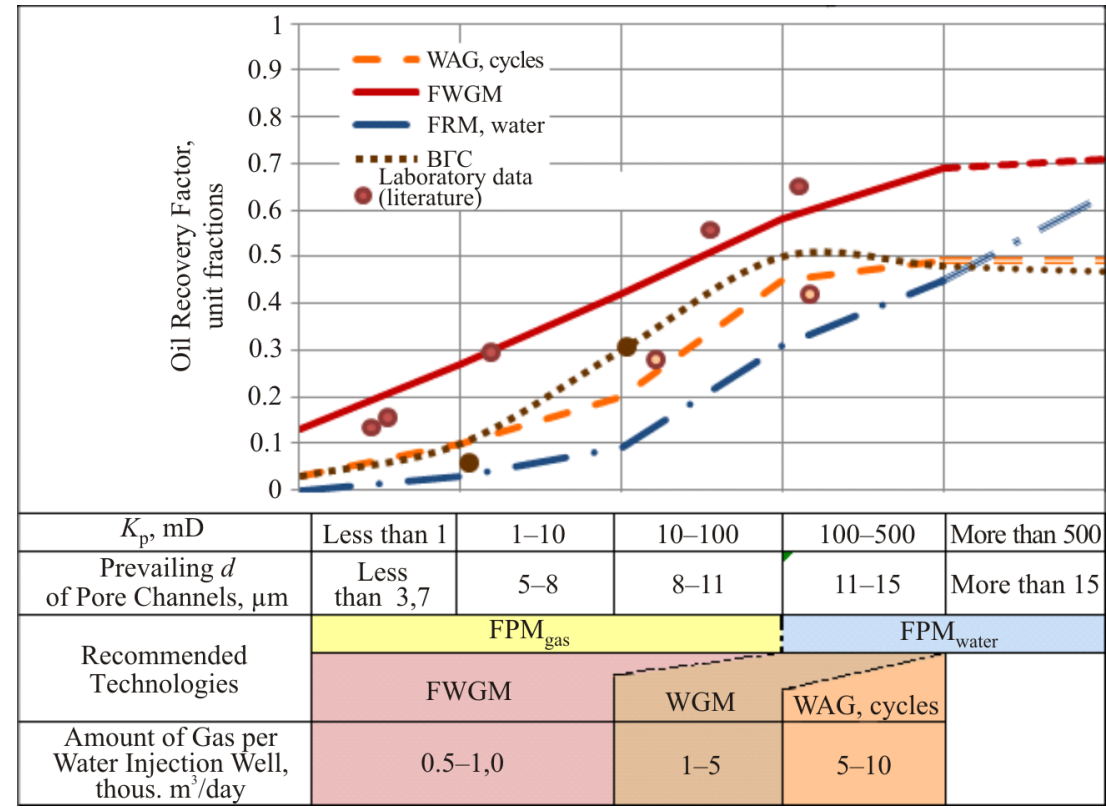

Fig. 2. Matrix of recommended technologies subject to working agent selection:

WAG is water-alternating-gas injection; FWGM is fine water-gas mixture;

FPM is formation pressure maintenance; WGM is water-gas mixture

Natural and induced in the course of development fracturing affects formation fluids flows. Opening of inclined fractures is practically impossible, since horizontal fractures do not participate in the flow process at later stages of development, and only vertical fractures in a 
certain geodynamic environment keep open and permit flow during well operation [16-17]. The key factor of the fracture permeability according to the dependency deduced by E.S. Romm (to determine the fracture permeability $K \mathrm{f}$ in rock sections under microscope) is not the intensity and length, but the openness of open fracture systems:

$$
K \mathrm{f}=A \cdot b^{3} \cdot l / S,(1)
$$

where $A$ is the proportionality coefficient; $b$ is fracture opening, $\mathrm{m} ; l$ is the fracture length, $\mathrm{m}$; $S$ is the area, $\mathrm{m}^{2}$.

As follows from the above expression, the twofold increase of the fracture intensity (or length) results in the twofold increase of the fracture permeability, while the twofold increase of the fracture openness results in the eight-fold increase in the fracture permeability. It also follows from the dependency (1) that the spatial pattern of the open fracture size will determine the anisotropy of reservoir permeability, intensity of the fluid inflow to the wellbore and its productivity. Therefore, it is necessary to perform an integrated structural/kinematic and tectonic/physical analysis of faults and prediction of fracture system parameters in the field development engineering.

During the integrated approach elaboration, considerable attention was paid to the working agents. The authors reviewed various technologies and technical solutions: FPM (water, gas), watergas mixture (WAG, injection of WGM or FWGM), gas lift, and barrier water-flooding [18-24]. In this case, the emphasis was made on the active development system characterized by attaining the maximum efficiency through the search of fundamentally new solutions and the refusal to upgrade traditional technologies [25]. In the process, gas acts as a positive component in oil and gas deposit development.

As a result of the current state of development analysis, it has been revealed that for practically every third field under development in the Perm Region, watercut surpasses recovery of reserves by more than $20 \%$. For this group of fields, a more detailed assessment of the expediency of using a classical injection agent - water - is recommended at the deposit level, with special attention paid to low-permeability reservoirs (less than 10-50 mD). A fundamentally new solution in this case will be the transition from a passive development system $\left(\mathrm{FPM}_{\text {water }}\right)$ to the introduction of WAG technologies (including the implementation of fine water-gas mixture (FWGM) injection. In this case, the method effectiveness will be determined by the ratio of gas bubble diameters to the typical sizes of pore channels, which should be less than one $[26,27]$. The gas phase dispersion, comparable to the size of pore channels, excludes premature gas breakthrough and provides the reduction of phase permeability for water in the narrowing of pore channels and additional scouring of wetting oil due to diffusion of gas bubbles into oil. Besides, a smaller gas bubbles diameter adds to the mixture stabilization and, as a consequence, provides more opportunities to adjust its performance properties [28].

As is known from the displacement theory, the fluid ratio of oil density to WGM density in reservoir conditions should be closely approximated. In this case we create preconditions for maximum possible oil displacement under other similar conditions [29-34]. The required WGM density is achieved by varying the volumetric watergas ratio subject to the density (mineralization) of the used water (dispersed medium):

$$
V_{\text {w.g }}=\text { gas volume/water volume. }
$$

According to bench and field tests, it should be in the range of 0.2-0.5 [35].

Consequently, oil density per se cannot be an unambiguous criterion when making a decision on the possibility of using the WGM technology on a hypothetical development facility. The following important physical parameter - viscosity - follows from the ratio of equal fluids density. In order to create the frontal displacement of oil from the pore matrix space, the necessary condition is the proximity or, better, some excess in the viscosity of injected WGM under reservoir conditions, i.e.

$$
\mu=\mu_{\mathrm{WGM}} / \mu_{\mathrm{oil}} \geq 1.1-1.2,
$$

where $\mu$ is the viscosity ratio of WGM to oil; $\mu_{\mathrm{WGM}}$ is the viscosity of injected water-gas mixture; $\mu_{\text {oil }}$ is oil viscosity. 
The increase in optimal WGM viscosity by approx. $10-20 \%$ is determined by the need to create a frontal displacement over the entire oilsaturated thickness of the developed facility. The dependency of viscosity on the concentration of the dispersed phase is linear and it is described by the Einstein's equation:

$$
\mu=\mu_{\mathrm{o}}(1+\alpha \varphi)
$$

where $\mu_{\mathrm{o}}$ is the viscosity of the dispersed medium (water); $\varphi$ is volume fraction of the dispersed phase (gas); and $\alpha$ is the particle drag coefficient (for spherical particles $\alpha=2.5$ ).

Equation (2) is fulfilled for dispersed systems that are subject to the Newton's law for fluids. As the concentration of the dispersed phase grows, the interaction between the particles increases, and strong deviations from the equation (2) are observed. The viscosity of concentrated systems grows exponentially in this case.

Another criterion for mixtures injection, apart from the above, is the presence of gas reserves in the fields. In this case, depending on the injection technology being implemented, the hydrocarbon gas injection rate per one water-gas injection well (element) is estimated to be from 0.5 to 10 thous. $\mathrm{m}^{3} /$ day (Table 2).

Table 2

Gas Injection Rate at WAG Source

\begin{tabular}{|l|c|c|}
\hline Technology & $\begin{array}{c}\text { Daily Gas Flow Rate, } \\
\text { thous. } \mathrm{m}^{3} / \text { day }\end{array}$ & $\begin{array}{c}\text { Gas Flow } \\
\text { Rate, } \\
\mathrm{mln}^{3} / \mathrm{y}\end{array}$ \\
\hline Water-Gas Cycle & $5-10$ & $1.8-3.7$ \\
\hline WGM & $1-5$ & $0.3-1.8$ \\
\hline FWGM & $0.5-1.0$ & $0.2-0.3$ \\
\hline
\end{tabular}

Consequently, virtually every seventh hydrocarbon field currently being exploited in the Perm Region has natural gas reserves (free or gas of gas caps) in the amount sufficient for the field trial of this technology [36-39].

However, to date, the comingled injection of water and gas still confronts technical difficulties. This, in turn, requires further upgrade of the preparation and injection equipment, which will ensure the creation of a stable water-gas mixture with the size of bubbles not exceeding the size of the pore channel, while meeting the cost-efficiency criteria (equipment and maintenance costs) [40].

Nevertheless, a common conclusion for all WAG application field tests carried out in the fields of Russia, USA, Norway and Canada is the effectiveness of oil displacement technologies based on the water-gas mixture injection. Oil recovery increase can reach $10-25 \%$ compared to conventional water-flooding [41-44].

As of today, the amount of remaining oil reserves of the LUKOIL-Perm Group of Companies exceeds 500 million tons. At the same time, in the structure of such oil reserves, under-gas-cap reserves account for approx. $7 \%$, low-permeability reservoirs (less than $5 \mathrm{mD}$ ) - for $37 \%$, and oil reserves with low thickness of reservoirs (less than $2 \mathrm{~m}$ ) - for about $3 \%$.

Thus, based on the existing structure of remaining recoverable reserves and the current state of field development, there is a clear need for future application of the active development technologies to achieve the target oil recovery rate in the LUKOIL-Perm Group of Companies.

\section{Application of Integrated Approach to the Development of Bashkirian Deposit of Oil and Gas Condensate Field}

As an example of the integrated approach with the implementation of active development technologies, let us examine an oil and gas condensate field in Perm Region. Having been under development since 1965, it is one of the largest fields in the region. It features difficult development conditions due to the specific geological structure. Three deposits: Bobrikovian, Tulian and Bashkirian, are complicated by gas caps. The Bashkirian deposit has the largest gas cap. Besides, there is a Vereian deposit of free gas in the field.

The simultaneous presence of gas-saturated, oil-saturated and water-saturated intervals in the section of the deposit causes, during interaction, the uncontrollable movement of oil-water and gasoil contacts in formations. Thus, in the 2000s there was a significant increase in oil-gas production in this field, while the volume of oil production 
remained unchanged. For a number of productive wells, there was a decline in the oil flow rate (conversion of oil wells operation to gas), which resulted in the shutdown of production well stock. To identify the reasons for oil-gas production growth, a cluster/genetic method of gas composition interpretation was developed and tested in 2002. This methodology, involving additional information on well operation, has enabled us to determine the share of oil gas and gas cap in the mixture, as well as to establish the existing drive of deposit development in the area of well drainage radius. Based on the results of gas sample composition processing, it was established that there are three types of gas in well production: gas of the gas cap, mixture gas and dissolved gas. The results of gas sample analysis are shown in the map section (Fig. 3, a).

In 2014, after 49 years of oil-only development, gas extraction from the gas cap of the Bashkirian deposit started at the field, which allowed reducing the negative trend. According to the current state of development, gas breakthroughs have been minimized for oil wells. The gas cap is shrinking according to the simulation results.

In accordance with the integrated approach and based on the current development state of the Bashkirian (Bsh) oil and gas facility, a commingled development is recommended subject to GOC immobility, as well as FWGM injection at the sites of field trials after the advance research on the current nature of saturation and deposit energy potential.

As part of the monitoring of the current development state, suggestions have been offered for the field under study to limit the injection agent volume and the injection pressure. Compliance with this operating mode for injection wells should result in the increased sweep efficiency of the reservoir pore matrix and reduced risk of induced hydraulic fracturing and water flow (water breakthrough) to productive formation wells [45].

In addition, when waterflooding starting points are being formed, special attention should be paid to the spatial patterns of fracture systems development. Thus, based on the results of the field data analysis for Tulian (Tl) - Bobrikovian
$\mathrm{Bb})$ reservoirs of the field under study, there were revealed spatial patterns of natural and induced vertical fractures propagation, with the azimuthal direction of $290-320^{\circ}$. The obtained patterns are very likely to correlate by area and section within the field outline.

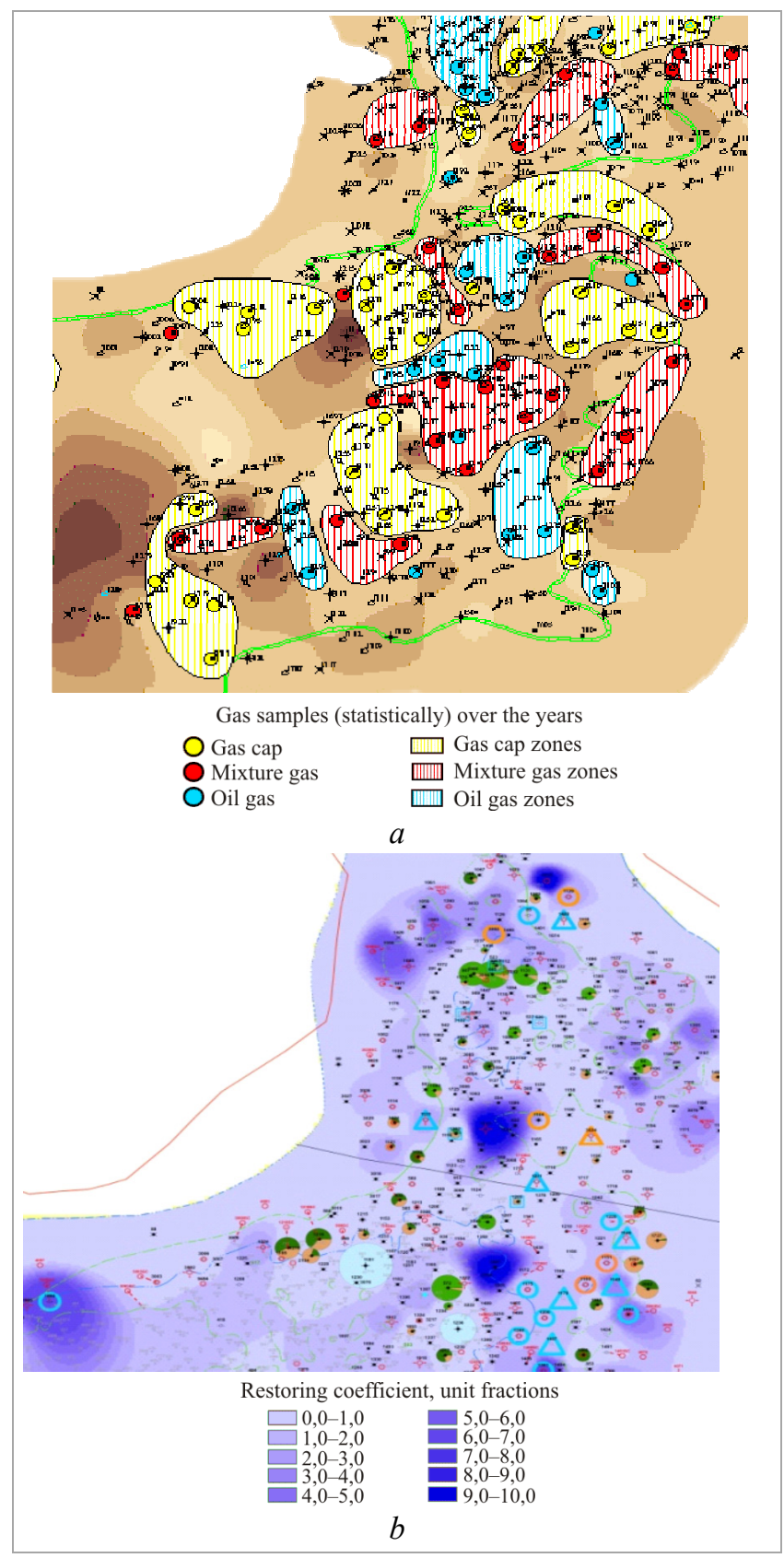

Fig. 3. Map: $a$-gas expansion in well production; $b$ - reservoir restoring coefficient distribution

As indicated earlier, part of the field production stock was idle. This started the so-called rehabilitation period, when, following the bulk shutdown of wells (change of the development 
cycle), in many areas there is accumulation of elastic reserves and redistribution of fluid [46].

To estimate the degree of reservoir restoration to the initial parameters (saturation behaviour and initial formation pressure) a map of reservoir restoring coefficient distribution was compiled. The distribution characterizes the ratio of idle time to operation time for a specific well (see Fig. 3, $b$ ). Natural repressuring of formation should lead to decompression opening of the porous fractured space and increase its permeability.

Under the analysis, the highest value of the formation system restoring coefficient corresponds to the areas with the maximum density of remaining oil reserves. The identified pattern allows us to determine the priority areas for the implementation of a set of measures, including the FWGM injection, especially for areas with low permeability reservoirs of less than $10 \mathrm{mD}$.

Following the results of the pilot remedial operations at individual facilities (separate wells), it is necessary to shift the emphasis to replication of the considered WAG technologies within the deposit in order to increase the sweep and the displacement efficiency.

\section{Conclusion}

The oil-gas deposit type is a measure of reserves; it predetermines system solutions for selecting an effective development technology. For efficient management of an oil-gas deposit development, oil and gas should be withdrawn in proportions that provide an equilibrium between the oil rim and the gas cap.

To determine the influence of natural and induced fracturing on the formation fluid flows, it is necessary to perform an integrated structural/ kinematic and tectonic/physical analysis of faults.

Increasing the oil recovery factor by $3 \%$ for the fields under development in the existing structure of oil reserves is equivalent to bringing into development of additional remaining reserves in place, comparable, as of today, to the annual growth of oil reserves through geological exploration. At the same time, the efficiency of unit costs for the implementation of active production methods, in particular, the WAG technology, is an order of magnitude higher than in the geological exploration.

International practice of field development, largely in the USA, Canada and Norway, where every second ton of oil is produced using the WAG technology, encourages us to implement active engineering solutions for oil and gas field development. The LUKOIL-PERM Group of Companies' assets with a potential to increase the oil recovery rate are mainly fields with natural gas reserves. Therefore, at oil-gas (gas-oil) fields, wherever possible and reasonable, natural gas should be considered as an instrument to bring oil reserves into development.

\section{References}

1. Zhukov Iu.A. et al. Analiz i utochnenie syrevoi bazy nefti, gaza i kondensata Permskogo kraia [Analysis and refinement of the raw material base of oil, gas and condensate in the Perm Territory]. PermNIPIneft. Perm, 2002, 194 p.

2. Razak E.A., Chan K.S., Darman N.B. Breaking oil recovery limit in Malaysian thin oil rim reservoirs: force balance revisited. Society of Petroleum Engineers. DOI: $10.2118 / 130388-M S$

3. Putten Van S., Naus M.T. Concurrent oil \& gas development wells: a smart well solution to thin oil rim presence in gas reservoirs.
International Petroleum Technology Conference. DOI: 10.2523/IPTC-12344-MS

4. Korotaev Iu.P., Shirkovskii A.I. Dobycha, transport i podzemnoe khranenie gaza [Gas production, transportation and underground storage]. Moscow, Nedra, 1984, $487 \mathrm{p}$.

5. Shirkovskii A.I. Razrabotka i ekspluatatsiia gazovykh i gazokondensatnykh mestorozhdenii [Engineering and operation of gas and gascondensate fields]. Moscow, Nedra, 1987, 309 p.

6. Zakirov S.N. Razrabotka gazovykh, gazokondensatnykh i neftegazokondensatnykh mestorozhdenii [Engineering of gas, gas- 
condensate and oil-gas-condensate fields]. Moscow, Struna, 1998, 628 p.

7. Shandrygin A.N. Sovmestnaia razrabotka neftianoi otorochki i gazovoi shapki: doklady prakticheskogo seminara [Commingled production of oil rim and gas cap: workshop reports]. Moscow, VNIGNI, 2014.

8. Olamigoke O., Peacock A. First-pass screening of reservoirs with large gas caps for oil rim development. Society of Petroleum Engineers. DOI: 10.2118/128603-MS

9. Grishin F.A. Podschet zapasov nefti i gaza v ssha [Calculation of oil and gas reserves in the USA]. Moscow, Nedra, 1993, 350 p.

10. Tulbovich B.I. Metody izucheniia porodkollektorov nefti i gaza [Methods for the study of reservoir rocks of oil and gas]. Moscow, Nedra, 1979, $199 \mathrm{p}$.

11. Dake L.P. Fundamentals of reservoir engineering. Amserdam, Elsevier, 1978, 443 p.

12. Dovzhok E.M., Balakirev Iu.A., Mirzoian L.E. Regulirovanie razrabotki i uvelichenie nefteotdachi plastov [Engineering control and enhanced oil recovery]. Kiev, Tekhnika, 1989, $144 \mathrm{p}$.

13. Khisamutdinov N.I. et al. Opyt povysheniia nefteotdachi plastov chereduiushcheisia zakachkoi dvuokisi ugleroda i vody [Experience in enhanced oil recovery by alternating injection of carbon dioxide and water]. Obzornaia informatsiia VNIIOENG. Moscow, 1981, iss.8, 64 p.

14. Kriuchkov V.I. Primenenie vodogazovykh sistem na osnove neftianogo gaza dlia uvelicheniia nefteizvlecheniia [The use of oilgas-based water-gas systems to increase oil recovery]. Abstract of $\mathrm{Ph}$. D. thesis. Bugulma, 2002, 19 p.

15. Masoudi R., Karkooti H., Othman M. How to get the most out of your oil rim reservoirs? International Petroleum Technology Conference. DOI: 10.2523/IPTC-16740-MS

16. Timurziev A.I. Tekhnologiia prognozirovaniia treshchinovatosti na osnove trekhmernoi geomekhanicheskoi i kinematicheskoi modeli treshchinnogo kollektora [Fracturing assessment via 3-D geological, mechanical and kinematic models of the fractured reservoir]. Geofizika, 2008, no.3, pp.41-60.
17. Khavkin A.Ia. Fiziko-khimicheskie aspekty protsessov vytesneniia nefti $\mathrm{V}$ poristykh sredakh [Physical and chemical aspects of oil displacement processes in porous media]. Geologiia, geofizika $i$ razrabotka neftianykh mestorozhdenii, 1994, no.7-10, pp.30-37.

18. Petrakov A.M., Simkin E.M., Egorov Iu.A. et al. Eksperimentalno-analiticheskoe issledovanie vytesneniia nefti gazom [Experimental and analytical studies of gas-oil displacement]. Oil industry, 2012, no. 10 , pp. $98-100$.

19. Stepanova G.S. Gazovye i vodogazovye metody vozdeistviia na neftianye plasty [Gas and water-gas methods for influencing oil reservoirs]. Moscow, Gazoil press, 2006, 200 p.

20. Asheim H. Criteria for gas-lift stability. Society of Petroleum Engineers. DOI: 10.2118/16468-PA.

21. Kabir M., McKenzie P., Connell C. Gas injection technique to develop rim oil, Mereenie Field. Australia. Society of Petroleum Engineers. DOI: $10.2118 / 50050-\mathrm{MS}$

22. Butorin O.I., Piiakov G.N. Obobshchenie eksperimentalnykh issledovanii po opredeleniiu effektivnosti primeneniia gazovogo i vodogazovogo vozdeistvii [Generalization of experimental studies to determine the effectiveness of the use of gas and gas effects]. Oilfield engineering, 1995, no.8, pp.54-59.

23. Bailey R.E. et al. Enhanced oil recovery. Natl. Petroleum Council, Industry Advisory Committee to the U.S. Washington, 1984.

24. Zatsepin V.V., Maksutov R.A. Sovremennoe sostoianie promyshlennogo primeneniia tekhnologii vodogazovogo vozdeistviia [Review of wag process industrial application. Modern consist]. Oilfield engineering, 2009, no.7, pp.13-21.

25. Viakhirev R.I., Korotaev Iu.P. Teoriia i opyt razrabotki prirodnykh gazov [Theory and experience of natural gas development]. Moscow, Nedra, 1999, 412 p.

26. Rozenberg M.D., Kundin S.A. Mnogofaznaia mnogokomponentnaia filtratsiia pri dobyche nefti i gaza [Multiphase multicomponent filtration in oil and gas production]. Moscow, Nedra, 1976, 336 p. 
27. Shevchenko A.K. K metodike opredeleniia vytesneniia nefti vodogazovoi smesiu na fizicheskikh modeliakh [On the methodology for determining the displacement of oil by a water-gas mixture on physical models]. Interval, 2007, no.2, pp.52-53.

28. Zemtsov Iu.V. Perspektivy dalneishego razvitiia primeneniia melkodispersnykh vodogazovykh smesei $\mathrm{v}$ kachestve vytesniaiushchego agenta [Perspectives in further development and application of fine-dispersed water-gas mixtures as oil-displacing agents]. Neft. Gaz. Novatsii, 2017, no.7, pp.34-38.

29. Botrkevich S.V., Savitskii N.V., Rassokhin S.G., Safiullina E.U. Metodika provedeniia filtratsionnykh eksperimentov dlia izucheniia melkodispersnoi vodogazovoi smesi [Methodology for conducting filtration experiments to study a finely dispersed water-gas mixture]. Oilfield engineering, 2004, no.2, pp.22-26.

30. Kuppe F., Chugh S., Kyles J.D. Modelling the reservoir mechanisms for gas cap blowdown of the Virginia Hills Belloy Reservoir. Petroleum Society of Canada. DOI: $10.2118 / 00-11-02$

31. Rassokhin S.G., Troitskii V.M., Mizin A.V. et al. Modelirovanie vodogazovogo vozdeistviia na nizkopronitsaemyi neftianoi plast [Modeling water-gas effects on a low-permeability oil reservoir]. Gazovaia promyshlennost, 2009, no.5, pp.40-44.

32. Hamoodi A.N., Abed A.F., Firoozabadi A. Compositional modelling of two-phase hydrocarbon reservoirs. Petroleum Society of Canada. DOI: $10.2118 / 01-04-03$

33. Coutinho R., Williams W., Waltrich P., Mehdizadeh P., Scott S. A model for liquidassisted gas-lift unloading. Conference Paper 18th International Conference on Multiphase Production Technology. Cannes, 2017. BHR Group. BHR-2017-345R.

34. Mehana M., Fahes M., Huang L. The density of oil/gas mixtures: insights from molecular simulations. Society of Petroleum Engineers. DOI: 10.2118/187297-PA,

35. Tekhniko-ekonomicheskoe obosnovanie obektov razrabotki dlia opytno-promyshlennykh ispytanii tekhnologii VGV po mestorozhdeniiam
OOO "LUKOIL-Perm" [Feasibility study of development facilities for pilot testing of $\mathrm{HBV}$ technology in the fields of LUKOIL-Perm LLC]. Otchet NIR. Filial "PermNIPIneft" v g. Permi. Perm, 2013, 174 p.

36. Simkin E.M. Mekhanizm doizvlecheniia ostatochnoi nefti pri vodogazovom vozdeistvii na obvodnennye plasty [The mechanism of residual oil recovery during water-gas impact on flooded formations]. Neftegazovye tekhnologii, 2011, no.6, pp.11-16.

37. Banerjee S. Developments and challenges of mature oil fields. Society of Petroleum Engineers. DOI: 10.2118/0313-011-TWA

38. Vafin R.V. Povyshenie effektivnosti tekhnologii vodogazovogo vozdeistviia na plast na alekseevskom mestorozhdenii [Improving the efficiency of water-gas treatment technology at the Alekseevskoye field]. Neftepromyslovoe delo, 2008, no.2, pp.33-35.

39. Shevchenko A.K., Chizhov S.I., Tarasov A.V. Predvaritelnye rezultaty zakachki V plast melkodispersnoi vodogazovoi smesi na pozdnei stadii razrabotki kotovskogo mestorozhdeniia [Preliminary results of fine-dispersed water-gas mixture injection into the reservoir at a late stage of Kotovskoye field development]. Oil industry, 2011, no.10, pp.100-102.

40. Zatsepin V.V. Opyt promyshlennoi realizatsii tekhnologii vodogazovogo vozdeistviia s zakachkoi vodogazovoi smesi v plast [Experience in industrial implementation of water-gas treatment technology with injection of a water-gas mixture into a reservoir]. Oilfield engineering, 2007, no.1, pp.10-14.

41. Petrakov A.M. et al. Analiz sovremennogo sostoianiia problemy vnedreniia tekhnologii vodogazovogo vozdeistviia dlia povysheniia nefteotdachi plastov $\mathrm{s}$ ispolzovaniem poputno dobyvaemogo neftianogo gaza [Analysis of the current state of the problem of introducing watergas treatment technologies to enhance oil recovery using associated oil gas]. Iss.147: Povyshenie effektivnosti razrabotki neftianykh mestorozhdenii. OAO "VNIINEFT"; pod red. D.Iu. Krianeva, S.A. Zhdanova. Moscow, 2012, pp.5-22. 
42. Baikov N.M. Zarubezhnyi opyt vnedreniia metodov uvelicheniia nefteotdachi [Foreign experience in introducing enhanced oil recovery methods]. Oil industry, 2008, no.12, pp.101-103.

43. Hinderaker L., Njaa S. Fri utilization of associated petroleum gas (APG) - The Norwegian Experience. Society of Petroleum Engineers. DOI: $10.2118 / 136316 \mathrm{MS}$

44. Pidcock G.A., Watson D.W. A review of Canadian frontier technology advances in the search for oil and gas. Petroleum Society of Canada. DOI: 10.2118/91-02-05
45. Kozlov S.V., Khrniak S.D. Dobycha prirodnogo gaza na territorii Permskogo kraia $\mathrm{V}$ voprosakh i otvetakh [Natural gas production in the Perm region in questions and answers]. Perm, Ai Kiu Press, 2012, 295 p.

46. Lozin E.V., Arzhilovskii A.V., Cherviakova A.N. et al. O gidrodinamicheskikh posledstviiakh massovoi ostanovki skvazhin $\mathrm{v}$ 90-kh godakh XX veka [About hydrodynamics effect after plural outage of wells in 90'slast century]. Oil industry, 2018, no.6, pp.62-65.

\section{Библиографический список}

1. Анализ и уточнение сырьевой базы нефти, газа и конденсата Пермского края / Ю.А. Жуков [и др.]; ПермНИПИнефть. Пермь, 2002. - 194 с.

2. Razak E.A., Chan K. S., Darman N.B. Breaking oil recovery limit in Malaysian thin oil rim reservoirs: force balance revisited / Society of Petroleum Engineers. DOI: $10.2118 / 130388-M S$

3. Putten Van S., Naus M.T. Concurrent oil \& gas development wells: a smart well solution to thin oil rim presence in gas reservoirs // International Petroleum Technology Conference. DOI: 10.2523/IPTC-12344-MS

4. Коротаев Ю.П., Ширковский А.И. Добыча, транспорт и подземное хранение газа: учеб. для вузов. - М.: Недра, 1984. - 487 с.

5. Ширковский А.И. Разработка и эксплуатация газовых и газоконденсатных месторождений. - М.: Недра, 1987. - 309 с.

6. Закиров С.Н. Разработка газовых, газоконденсатных и нефтегазоконденсатных месторождений. - М.: Струна, 1998. - 628 с.

7. Шандрыгин А.Н. Совместная разработка нефтяной оторочки и газовой шапки: доклады практического семинара. - М.: ВНИГНИ, 2014.

8. Olamigoke O., Peacock A. First-pass screening of reservoirs with large gas caps for oil rim development // Society of Petroleum Engineers. DOI: 10.2118/128603-MS

9. Гришин Ф.А. Подсчет запасов нефти и газа в США. - М.: Недра, 1993. - 350 с.
10. Тульбович Б.И. Методы изучения пород-коллекторов нефти и газа. - М.: Недра, 1979. - 199 c.

11. Dake L.P. Fundamentals of reservoir engineering. - Amserdam: Elsevier, 1978. $443 \mathrm{p}$.

12. Довжок Е.М., Балакирев Ю.А., Мирзоян Л.Э. Регулирование разработки и увеличение нефтеотдачи пластов. - Киев.: Техника, 1989. - $144 \mathrm{c}$.

13. Опыт повышения нефтеотдачи пластов чередующейся закачкой двуокиси углерода и воды / Хисамутдинов Н.И. [и др.] // Обзорная информация ВНИИОЭНГ. - М., 1981. Вып. 8. - 64 с.

14. Крючков В.И. Применение водогазовых систем на основе нефтяного газа для увеличения нефтеизвлечения: автореф. дис. ... канд. техн. наук. - Бугульма, 2002. - 19 с.

15. Masoudi R., Karkooti H., Othman M. How to get the most out of your oil rim reservoirs? International Petroleum Technology Conference. DOI: 10.2523/IPTC-16740-MS

16. Тимурзиев А.И. Технология прогнозирования трещиноватости на основе трехмерной геомеханической и кинематической модели трещинного коллектора // Геофизика. - 2008. № 3. - C. 41-60.

17. Хавкин А.Я. Физико-Химические аспекты процессов вытеснения нефти в пористых средах // Геология, геофизика и разработка нефтяных месторождений. - 1994. № 7-10. - C. $30-37$. 
18. Экспериментально-аналитическое исследование вытеснения нефти газом / А.М. Петраков, Э.М. Симкин, Ю.А. Егоров [и др.] // Нефтяное хозяйство. - 2012. - № 10. C. $98-100$.

19. Степанова Г.С. Газовые и водогазовые методы воздействия на нефтяные пласты. - М.: Газоил пресс, 2006. - 200C.

20. Asheim H. Criteria for gas-lift stability / Society of Petroleum Engineers. DOI: 10.2118/16468-PA.

21. Kabir M., McKenzie P., Connell C. Gas injection technique to develop rim oil, Mereenie Field, Australia. Society of Petroleum Engineers. DOI: $10.2118 / 50050-\mathrm{MS}$

22. Буторин О.И., Пияков Г.Н. Обобщение экспериментальных исследований по определению эффективности применения газового и водогазового воздействий // Нефтепромысловое дело. - 1995. - № 8. C. 54-59.

23. Enhanced oil recovery / R.E. Bailey [et al.] // Natl. Petroleum Council, Industry Advisory Committee to the U.S. - Washington, 1984.

24. Зацепин В.В., Максутов Р.А. Современное состояние промышленного применения технологий водогазового воздействия // Нефтепромысловое дело. 2009. - № 7. - С. 13-21.

25. Вяхирев Р.И., Коротаев Ю.П. Теория и опыт разработки природных газов. - М.: Недра, 1999. $-412 \mathrm{c}$.

26. Розенберг М.Д., Кундин С.А. Многофазная многокомпонентная фильтрация при добыче нефти и газа. - М.: Недра, 1976. - 336 с.

27. Шевченко А.К. К методике определения вытеснения нефти водогазовой смесью на физических моделях // Интервал. - 2007. № 2. - С. 52-53.

28. Земцов Ю.В. Перспективы дальнейшего развития применения мелкодисперсных водогазовых смесей в качестве вытесняющего агента // Нефть. Газ. Новации. - 2017. - № 7. C. 34-38.

29. Методика проведения фильтрационных экспериментов для изучения мелкодисперсной водогазовой смеси / С.В. Ботркевич, Н.В. Савицкий,
С.Г. Рассохин, Е.У. Сафиуллина // Нефтепромысловое дело. - 2004. - № 2. - С. 22-26.

30. Kuppe F., Chugh S., Kyles J.D. Modelling the reservoir mechanisms for gas cap blowdown of the virginia hills belloy Reservoir / Petroleum Society of Canada. DOI: 10.2118/00-11-02

31. Моделирование водогазового воздействия на низкопроницаемый нефтяной пласт / С.Г. Рассохин, В.М. Троицкий, А.В. Мизин [и др.] // Газовая промышленность. 2009. - № 5. - C. 40-44.

32. Hamoodi A.N., Abed A.F., Firoozabadi A. Compositional modelling of two-phase hydrocarbon reservoirs / Petroleum Society of Canada. DOI: 0.2118/01-04-03

33. Coutinho R., Williams W., Waltrich P., Mehdizadeh P., Scott S. A model for liquidassisted gas-lift unloading // Conference Paper 18th International Conference on Multiphase Production Technology. - Cannes, 2017. BHR-2017-345R.

34. Mehana M., Fahes M., Huang L. The density of oil/gas mixtures: insights from molecular simulations / Society of Petroleum Engineers. DOI: 10.2118/187297-PA

35. Технико-экономическое обоснование объектов разработки для опытнопромышленных испытаний технологии ВГВ по месторождениям ООО «ЛУКОЙЛ-Пермь»: отчет НИР / Филиал «ПермНИПИнефть» в г. Перми. - Пермь, 2013. - 174 с.

36. Симкин Э.М. Механизм доизвлечения остаточной нефти при водогазовом воздействии на обводненные пласты // Нефтегазовые технологии. - 2011. - № 6. C. 11-16.

37. Banerjee S. Developments and challenges of mature oil fields / Society of Petroleum Engineers. DOI: 10.2118/0313-011-TWA

38. Вафин Р.В. Повышение эффективности технологии водогазового воздействия на пласт на Алексеевском месторождении // Нефтепромысловое дело. - 2008. - № 2. C. $33-35$.

39. Шевченко А.К., Чижов С.И., Тарасов А.В. Предварительные результаты закачки в пласт мелкодисперсной водогазовой смеси на 
поздней стадии разработки Котовского месторождения // Нефтяное хозяйство. 2011. - № 10. - C. 100-102.

40. Зацепин В.В. Опыт промышленной реализации технологии водогазового воздействия с закачкой водогазовой смеси в пласт // Нефтепромысловое дело. - 2007. № 1. - С. 10-14.

41. Анализ современного состояния проблемы внедрения технологий водогазового воздействия для повышения нефтеотдачи пластов с использованием попутно добываемого нефтяного газа / А.М. Петраков [и др.] // Вып. 147: Повышение эффективности разработки нефтяных месторождений / ОАО «ВНИИнефть»; под ред. Д.Ю. Крянева, С.А. Жданова. - М., 2012. - С. 5-22.

42. Байков H.M. Зарубежный опыт внедрения методов увеличения нефтеотдачи //
Нефтяное хозяйство. - 2008. - № 12. C. 101-103.

43. Hinderaker L., Njaa S. Fri utilization of associated petroleum gas (APG) - the Norwegian experience / Society of Petroleum Engineers. DOI: $10.2118 / 136316-\mathrm{MS}$

44. Pidcock G.A., Watson D.W. A review of Canadian frontier technology advances in the search for oil and gas / Petroleum Society of Canada. DOI: 10.2118/91-02-05

45. Козлов С.В., Хрняк С.Д. Добыча природного газа на территории Пермского края в вопросах и ответах. - Пермь: Ай Кью Пресс, 2012. $-295 \mathrm{c}$.

46. О гидродинамических последствиях массовой остановки скважин в 90-х годах XX века / Е.В. Лозин, А.В. Аржиловский, А.Н. Червякова [и др.] // Нефтяное хозяйство. 2018. - № 6. - C. 62-65.

Please cite this article in English as:

Goncharova O.R., Kozlov S.V. Enhancing the efficiency of gas-oil (oil-gas) deposits development based on selection of optimal engineering solutions for Perm Region fields. Perm Journal of Petroleum and Mining Engineering, 2020, vol.20, no.1, pp.88-100. DOI: $10.15593 / 2224-9923 / 2020.1 .8$

Просьба ссылаться на эту статью в русскоязычных источниках следующим образом:

Гончарова О.Р., Козлов С.В. Повышение эффективности разработки газонефтяных (нефтегазовых) залежей на основе подбора оптимальных проектных решений для месторождений Пермского края // Вестник Пермского национального исследовательского политехнического университета. Геология. Нефтегазовое и горное дело. - 2020. - Т.20, №1. C.88-100. DOI: 10.15593/2224-9923/2020.1.8 